\title{
NOTE
}

\section{Epitopes associated with mature spores not recognized on Kudoa thyrsites from recently infected Atlantic salmon smolts}

\author{
Catherine A. Young ${ }^{1}$, Simon R. M. Jones ${ }^{2, *}$ \\ ${ }^{1}$ Department of Biology, University of Victoria, Victoria, British Columbia V8W 3N5, Canada \\ ${ }^{2}$ Pacific Biological Station, Department of Fisheries and Oceans, 3190 Hammond Bay Road, Nanaimo, \\ British Columbia V9R 5K6, Canada
}

\begin{abstract}
Atlantic salmon Salmo salar skeletal muscle was examined for Kudoa thyrsites by polymerase chain reaction (PCR) and positive fish were further examined by in situ hybridization (ISH) and immunohistochemistry (IHC). The infection was detected in $42 \%$ of salmon by PCR following a $60 \mathrm{~d}$ exposure to infective seawater at a temperature of $10^{\circ} \mathrm{C}\left(=600\right.$ degree-days, $\left.{ }^{\circ} \mathrm{D}\right)$. The parasite was detected by ISH in skeletal and cardiac muscle but not in gill, kidney, spleen, liver, stomach, intestine, pyloric caeca and skin. None of 4 monoclonal antibodies $(2 \mathrm{~F} 4,4 \mathrm{H} 2,1 \mathrm{H} 2,3 \mathrm{E} 8)$ raised against mature $K$. thyrsites spores reacted with the stages identified by ISH following a $600{ }^{\circ} \mathrm{D}$ exposure, but they did react with ISH-identified stages following a $1600{ }^{\circ} \mathrm{D}$ exposure. In contrast, a polyclonal antibody reacted with $K$. thyrsites stages in salmon with both 600 and $1600{ }^{\circ} \mathrm{D}$ exposures, suggesting that the parasite observed in $600^{\circ} \mathrm{D}$ infections represents an antigenically distinct developmental stage of $K$. thyrsites.
\end{abstract}

KEY WORDS: Kudoa thyrsites $\cdot$ Myxosporea $\cdot$ Salmo salar $\cdot$ In situ hybridization $\cdot$ Immunohistochemistry

\section{INTRODUCTION}

Kudoa thyrsites (Myxozoa: Myxosporea) has a global distribution and wide host range, including commercially important Atlantic Salmo salar, chinook Oncorhynchus tshawytscha, and coho Oncorhynchus kisutch salmon (Kabata \& Whitaker 1989, Moran et al. 1999b). The life cycle of $K$. thyrsites is unknown but, as with other Myxosporea (Kent et al. 2001), it is thought to include developmental stages within both the fish and an alternate invertebrate host (Moran et al. 1999c). Infection in salmon occurs upon seawater entry by exposure to a presumptive water-borne infective stage. Members of some myxosporean genera, such as Myxobolus and Sphaerospora have one or more developmental stages within their fish hosts in tissues remote from the ultimate site of sporulation (Csaba
1976, El-Matbouli et al. 1995). Moran et al. (1999c) showed that $K$. thyrsites infection could be transmitted to naïve Atlantic salmon by injecting blood from an infected fish, suggesting that an extra-sporogonic stage (or stages) may occur in the blood of salmonids.

Mature spores and plasmodia of Kudoa thyrsites are detected by microscopic examination of fresh or histological preparations of skeletal muscle (Whitaker \& Kent 1991), by PCR (Hervio et al. 1997) or by in situ hybridization (ISH) (Jones et al. 2003). Earlier developmental stages of the parasite are neither commonly reported nor well characterized. For example, PCR was used to detect infection in several Atlantic salmon tissues as early as $4 \mathrm{wk}$ post seawater-exposure (p.e.) (Moran et al. 1999a). The earliest reported detection by histology occurred at about 2 mo p.e., with what were apparently pre-sporogonic plasmodia observed in the 
skeletal muscle, whereas developmental stages were first reported 17 wk p.e. in cardiac muscle (Moran et al. 1999a). The immunohistochemical examination of $K$. thyrsites stages in recently $(60 \mathrm{~d})$ exposed Atlantic salmon formed the basis of the present study.

\section{MATERIALS AND METHODS}

Approximately 100 Atlantic salmon smolts (average length: $173 \mathrm{~mm}$, average weight: $61.2 \mathrm{~g}$ ) were held in tanks and exposed to flowing seawater from Departure Bay, Nanaimo, British Columbia, in which the parasite is enzootic (Moran et al. 1999c). The fish were fed a commercial diet for the duration of the study. After $60 \mathrm{~d}$ exposure at a constant seawater temperature of $10^{\circ} \mathrm{C}$ (=600 degree-days, $\left.{ }^{\circ} \mathrm{D}\right)$, fish were killed by immersion in MS-222 and samples of blood, heart, spleen, liver, anterior kidney, posterior kidney, eye, gill, stomach, pyloric caeca, lower intestine and skeletal muscle (including skin), were collected. Tissues were preserved in phosphate-buffered $10 \%$ formalin ( $\mathrm{pH} 7.0$ ) for $24 \mathrm{~h}$, followed by two $24 \mathrm{~h}$ washes with $95 \%$ ethanol. Additional skeletal muscle samples were harvested aseptically and frozen at $-20^{\circ} \mathrm{C}$ for examination by polymerase chain reaction (PCR). Fixed tissues were dehydrated through an increasing alcohol gradient and embedded in paraffin. We mounted $5 \mu \mathrm{m}$ sections onto aminoalkylsilane-treated glass slides (Sigma Diagnostics) for ISH and immunohistochemistry. Similar tissues from exclusively freshwater-reared salmon (negative controls) and from $1600{ }^{\circ} \mathrm{D}$ seawaterexposed salmon with previously confirmed infections (positive controls) were collected and processed as described above.

DNA was extracted from $~ 25$ mg skeletal muscle from each fish, using the Qiagen Dneasy tissue kit according to manufacturer's instructions. Aliquots of $1.5 \mu \mathrm{l}$ of extracted DNA $\left(<50 \mu \mathrm{g} \mathrm{ml}^{-1}\right)$ were then used as template in PCR reactions to amplify a 531 base-pair fragment of the Kudoa thyrsites 18S rRNA gene (Jones et al. 2003).

Tissues from PCR-positive fish were assayed by ISH using the protocol of Jones et al. (2003). Briefly, tissue sections were de-paraffinized in an increasing alcohol gradient and permeabilized for $10 \mathrm{~min}$ in cold $\left(-20^{\circ} \mathrm{C}\right)$ acetone. Sections were rinsed twice in phosphatebuffered saline (PBS), followed by an incubation in acetic anhydride and $0.1 \mathrm{M}$ triethanolamine ( $\mathrm{pH} 8.0)$, and a subsequent wash in PBS and 2 washes in $4 \times$ SSC (0.6 M NaCl, $0.06 \mathrm{M}$ sodium citrate). Sections were incubated for $1 \mathrm{~h}$ in hybridization buffer $(51 \%$ deionized formamide, $20 \% 20 \times \mathrm{SSC}, 1 \%$ dextran sulfate, $0.5 \mathrm{mg} \mathrm{ml}^{-1}$ heat-denatured herring sperm DNA, 1× Denhardt's $[0.02 \%$ acetylated bovine serum albumin, $0.02 \%$ polyvinylpyrrolidone, $0.02 \%$ Ficoll 400$]$, and
$0.025 \%$ sodium dodecyl sulfate). The DIG_KUDISH5r probe $\left(5^{\prime}\right.$-ATTTGGCACTTGCGTACGC-3') was applied at $3 \mathrm{ng} \mathrm{pl}^{-1}$ and the sections were coverslipped and heated to $95^{\circ} \mathrm{C}$ for $5 \mathrm{~min}$. The covered sections were incubated overnight at $37^{\circ} \mathrm{C}$. After hybridization, sections were washed twice in $4 \times$ SSC. The hybridized probe was detected by following the DIG Nucleic Acid Detection Kit protocol (Roche Diagnostics). Sections were counterstained in Bismarck Brown Y (2 min), dehydrated in alcohol and xylene, and coverslipped with Permount prior to microscopic observation and photography.

Cardiac and skeletal muscle sections from three $600{ }^{\circ} \mathrm{D}$-exposed fish that were identified by ISH as heavily infected were also examined by immunohistochemistry (IHC). IHC with each primary poly- and monoclonal antibody was also performed on skeletal muscle sections from fish with $1600^{\circ} \mathrm{D}$ exposure. Serial sections $(5 \mu \mathrm{m})$ were alternately assayed with either ISH or IHC, allowing direct comparison between locations on sequential slides. We tested 4 monoclonal antibodies (mAb: 2F4, 4H2, 1H2 and 3E8; Chase et al. 2001 ) and 1 polyclonal antibody (pAb) raised in rabbits against mature Kudoa thyrsites spores as described in Chase et al. (2003). Tissue sections were deparaffinized and rehydrated in phosphate-buffered saline (PBS) ( $\mathrm{pH} 7.4$ ), plus $0.15 \%$ Tween-20 (PBS/T). Tissues were permeabilized in ice-cold acetone at $-20^{\circ} \mathrm{C}$ for $10 \mathrm{~min}$, and rinsed in PBS/T. Slides were incubated with $200 \mu \mathrm{l}$ of primary antibody (mAb undiluted, pAb dilution 1:10,000, in PBS/T), at room temperature for $1 \mathrm{~h}$ in a humid chamber. Monoclonal antibodies were tested individually or combined in pools of 2 (IH2 and 3E8, 2F4 and 4H2) or 4. Slides were first rinsed $(5 \times 1 \mathrm{ml})$, then washed 3 times in PBS/T and incubated with $200 \mu \mathrm{l}$ of secondary antibody (1:50 dilution in PBS/T) (mAb: alkaline phosphatase [AP] conjugated goat anti-mouse immunoglobin, IgG and IgM $[\mathrm{H}+\mathrm{L}] ;$ pAb: AP-conjugated goat anti-rabbit IgG $[\mathrm{H}+\mathrm{L}]$; Jackson Immunoresearch Laboratories), for $45 \mathrm{~min}$ in a humid chamber. Slides were washed as above. Sections were incubated for $2 \mathrm{~h}$ with $200 \mu \mathrm{l}$ of nitro blue tetrazolium/bromochloroindolyl phosphate (NBT/BCIP) substrate (1/50 dilution), and washed in deionized, distilled $\mathrm{H}_{2} \mathrm{O}$ to stop the reaction. Sections were counterstained in Bismarck Brown Y, dehydrated in alcohol and xylene, and coverslipped with Permount prior to microscopic observation and photography. Controls included incubation of primary and secondary antibodies with tissue sections from non-exposed fish, as well as incubation of infected muscle with a nonspecific primary antibody, followed by secondary antibody. ISH and IHC preparations were viewed with a Leitz Dialux 22 series microscope and micrographs were taken using a Nikon Coolpix 995 camera. 


\section{RESULTS}

\section{Polymerase chain reaction and in situ hybridization}

Kudoa thyrsites was detected by PCR in the skeletal muscle of $42 \%(43 / 102)$ of salmon sampled after $600{ }^{\circ} \mathrm{D}$ of seawater exposure. Positive ISH signals were detected in the skeletal muscle of $51 \%(22 / 43)$ of PCRpositive fish. Of these, 16 fish also showed strong ISH signals in cardiac muscle. Variability in the intensity of the ISH signal among samples was noted, with some sections showing multiple strong signals, while others displayed much smaller and weaker signals. Staining was observed in both white and red skeletal muscle, as well as in muscle fibers associated with the eye and gill. No staining was observed in any other tissue. Strong signals were observed in all positive control sections, whereas sections from naïve fish were consistently negative.

\section{Immunohistochemistry}

None of the $4 \mathrm{mAbs}$, either alone or as pools, reacted with Kudoa thyrsites in $600^{\circ} \mathrm{D}$-exposed fish (Fig. 1B). The presence of the parasite was confirmed by ISH staining in flanking serial sections (Fig. 1A,C). In contrast, strong IHC reactivity was observed in serial sections from $600{ }^{\circ} \mathrm{D}$-exposed fish assayed with the pAb (Fig. 1D). Strong staining was observed for each of the $4 \mathrm{mAbs}$ and the pAb in muscle sections from fish with $1600{ }^{\circ} \mathrm{D}$ exposure (Fig. 2). Negative control assays consistently showed no staining following incubation with either the mAb or pAb.


Fig. 1. Detection of Kudoa thyrsites in cardiac muscle from Atlantic salmon Salmo salar with 600 degree-day seawater exposure by in situ hybridization (ISH) and immunohistochemistry (IHC). Serial sections show staining by (A) ISH and (B) monoclonal antibody 1H2 . Arrow marks location of parasite in (B). Results for $1 \mathrm{H} 2$ are representative of those for 3 additional monoclonal antibodies tested (2F4, 4H2, 3E8), each of which failed to react with $K$. thyrsites stages in both cardiac and skeletal muscle, whereas $K$. thyrsites in flanking sections was intensely stained with ISH. In contrast, $K$. thyrsites was detected in serial sections of cardiac muscle stained with (C) ISH and (D) polyclonal antibody. Similar results were observed for skeletal muscle. Scale bars $=10 \mu \mathrm{m}$ 

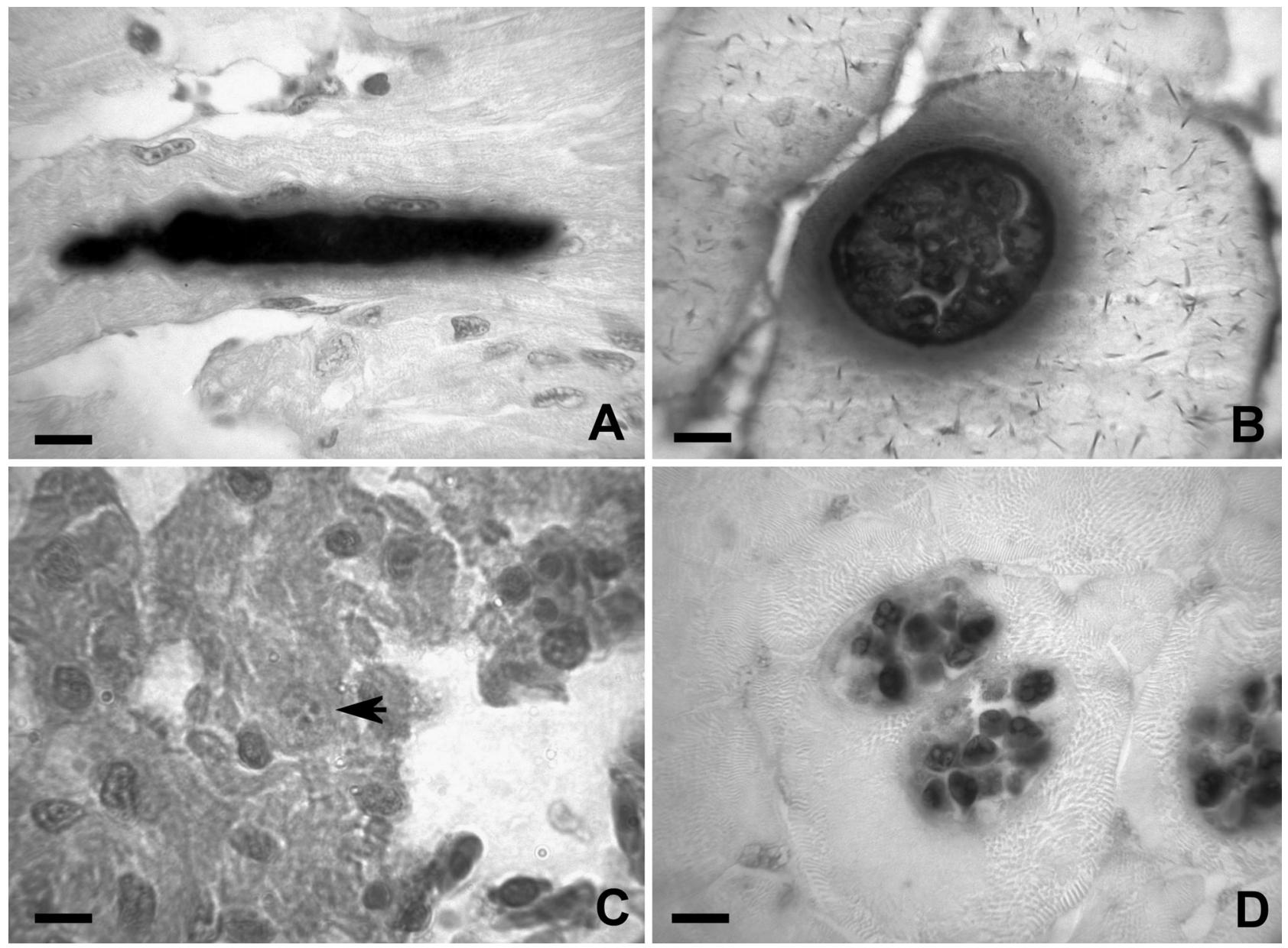

Fig. 2. Detection of Kudoa thyrsites in Atlantic salmon Salmo salar by immunohistochemistry. Polyclonal antibody detects $K$. thyrsites in muscle tissue with (A) 600 and (B) 1600 degree-days $\left({ }^{\circ} \mathrm{D}\right)$ seawater exposure. In contrast, monoclonal antibodies (mAbs) do not react with stages of $K$. thyrsites from $600{ }^{\circ} \mathrm{D}$-exposed salmon (arrow, C), but do react strongly with mature spores (D) from $1600{ }^{\circ} \mathrm{D}$-exposed salmon. Results shown are for mAb 3E8, and are representative of those for each mAb tested (2F4, $4 \mathrm{H} 2,1 \mathrm{H} 2$ ) individually and pooled. Scale bars $=10 \mu \mathrm{m}$

\section{DISCUSSION}

The presence of Kudoa thyrsites in Atlantic salmon smolts following a relatively brief $\left(600^{\circ} \mathrm{D}\right)$ exposure was demonstrated using polymerase chain reaction and confirmed by ISH. The apparent difference in infection rates suggested by PCR and ISH was probably due to differences in the amounts of tissue assayed or to differences in the sensitivities of these assays. Well-differentiated spore-like structures were clearly visualized within the $600^{\circ} \mathrm{D}$ plasmodia and, at this time, stained strongly using ISH. In contrast, ISH of $K$. thyrsites from the $1600{ }^{\circ} \mathrm{D}$ infections resulted in strong staining around the periphery of the plasmodia but the mature spores remained largely unstained probably due to poor permeability of the probe, similar to observations of Jones et al. (2003). Further examination of histological preparations using reagents that better resolve structural detail, such as Gram or Giemsa stains, or transmission electron microscopy are required to accurately identify these $K$. thyrsites developmental stages. Their relatively intense ISH staining, however, suggested that they were pre-sporogonic.

Immunohistochemical assays showed all 4 monoclonal antibodies to be reactive with Kudoa thyrsites in formalin-fixed, paraffin-embedded sections from fish exposed for $1600{ }^{\circ} \mathrm{D}$. However, evidence of a previously unrecognized developmental complexity for K. thyrsites was provided by the failure of the $600^{\circ} \mathrm{D}$ stages to react with any of the 4 monoclonal antibodies despite the ready detection of these stages using a polyclonal antibody. The strong ISH signals observed in flanking sections confirmed the specific location of the stages that failed to react with the monoclonal antibodies. This suggested that certain epitopes present in mature spores are sequentially expressed during 
parasite development, and that those recognized by the monoclonal antibodies were not yet present in the stages examined after the $600{ }^{\circ} \mathrm{D}$ exposure. It is unlikely that the differences in antibody reactivity were the result of the loss or masking of the epitopes, since samples from both 600 and $1600^{\circ} \mathrm{D}$ infections were fixed and assayed in an identical manner. The monoclonal antibodies recognized epitopes associated with the polar capsule and filament $(1 \mathrm{H} 2,3 \mathrm{E} 8)$ and with the spore surface (2F4, 4H2) (Chase et al. 2001). Furthermore, the surface epitope recognized by mAb $4 \mathrm{H} 2$ is associated with an abundant carbohydrate (Chase et al. 2001). Reactivity with the high-titer polyclonal antibody further suggested that in addition to those that are sequentially expressed, other epitopes are consistently expressed throughout development. Together, results from the ISH and IHC assays suggested that pre-sprogonic stages of $K$. thyrsites present after $600{ }^{\circ} \mathrm{D}$ of exposure do not express epitopes that are associated with the polar capsule, polar filament and valve surface of mature spores. We are presently attempting to better characterize these early stages by purification and immunoblotting and to establish the expression kinetics of serologically reactive parasite antigens.

Detection and characterization of the early development of Kudoa thyrsites within muscle had previously relied on PCR and light microscopy (Moran et al. 1999a). PCR is a sensitive assay and allows early detection but provides little information on parasite locality in specific tissues. Similarly, localization of recognizable mature infections is possible with histological staining, but does not allow characterization of obscure developmental stages. This study has shown the effectiveness of combining ISH and immunohistochemistry to characterize previously undescribed developmental stages of $K$. thyrsites. ISH was confirmed to be an effective tool in localizing $K$. thyrsites to specific tissues and in visualizing cryptic stages. Confirming the presence of these cryptic stages provided the opportunity to examine their reactivity by IHC. While polyclonal antisera may be useful in the early detection of $K$. thyrsites infection, the monoclonal antibodies, by recognizing epitopes only expressed on mature spores, will be poorly suited to this application.

Several questions relating to the transmission and early pathogenesis of Kudoa thyrsites remain unresolved. Exposure to the infective stage of $K$. thyrsites is measured from seawater entry, and infection is assumed to occur as of that time, but whether infection occurs by continuous or intermittent exposure to a putative infective stage is not clear. The relatively low prevalence $(42 \%)$ of infection following $600{ }^{\circ} \mathrm{D}$ exposure suggested that infection occurs gradually, perhaps by trickle-exposure to a water-borne infective stage. The nature of this exposure pattern could be explored by direct monitoring of seawater for the infective stage and through an improved understanding of parasite development within the fish.

Acknowledgements. The authors thank Dr. T. W. Pearson, University of Victoria for providing the polyclonal and monoclonal antibodies used in this study and Dr. A. W. Gibson, Malaspina University College, for suggesting improvements to the manuscript. Thanks also to Kimberley Taylor for help with sampling and histology and Robert Kennedy for fish care and maintenance. Financial assistance for this study was provided by the ACRD Program of Fisheries and Oceans Canada and by the British Columbia Salmon Farmers Association.

\section{LITERATURE CITED}

Chase JC, Dawson-Coates JA, Haddow JD, Stewart MH and 5 others (2001) Analysis of Kudoa thyrsites (Myxozoa: Myxosporea) spore antigens using monoclonal antibodies. Dis Aquat Org 45:121-129

Chase JC, Booy MH, Dawson-Coates JA, Haddow JD, Haines LR, Whitaker DJ, Olafson RW, Pearson TW (2003) Immunological detection of Kudoa thyrsites spores in muscle tissues of farmed Atlantic salmon, Salmo salar L. J Fish Dis 26:427-431

Csaba G (1976) An unidentifiable extracellular sporozoan parasite from the blood of the carp. Parasitol Hung 9: $21-24$

El-Matbouli M, Hoffman C, Mandok C (1995) Light and electron microscopic observations on the route of the triactinomyxon-sporoplasm of Myxobolus cerebralis from epidermis into rainbow trout cartilage. J Fish Biol 46: 919-935

Hervio DML, Kent ML, Khattra J, Sakanari J, Yokoyama H, Devlin RH (1997) Taxonomy of Kudoa species (Myxosporea) using a small-subunit ribosomal DNA sequence. Can J Zool 75:2112-2119

Jones SRM, Goh B, Prosperi-Porta G (2003) Duration and method of fixation affects the sensitivity of a digoxygeninlabelled DNA probe in detecting Kudoa thyrsites in Atlantic salmon skeletal muscle. Aquaculture 220:157-164

Kabata Z, Whitaker DJ (1989) Kudoa thyrsites (Gilchrist, 1924) (Myxozoa) in the cardiac muscle of Pacific salmon (Oncorhynchus spp.) and steelhead trout (Salmo gairdneri). Can J Zool 67:341-342

Kent ML, Andree KB, Bartholomew JL, El-Matbouli M and 12 others (2001) Recent advances in our knowledge of the Myxozoa. J Eukaryot Microbiol 48:395-413

Moran JDW, Margolis L, Webster JM, Kent ML (1999a) Development of Kudoa thyrsites (Myxozoa: Myxosporea) in netpen-reared Atlantic salmon determined by light microscopy and a polymerase chain reaction test. Dis Aquat Org 37:185-193

Moran JDW, Whitaker DJ, Kent ML (1999b) A review of the myxosporean genus Kudoa Meglitsch, 1947, and its impact on the international aquaculture industry and commercial fisheries. Aquaculture 172:163-196

Moran JDW, Whitaker DJ, Kent ML (1999c) Natural and laboratory transmission of the marine myxozoan parasite Kudoa thyrsites to Atlantic salmon. J Aquat Anim Health 11:110-115

Whitaker DJ, Kent ML (1991) Kudoa thyrsites (Myxosporea): a cause of soft flesh in farm-reared Atlantic salmon (Salmo salar). J Aquat Anim Health 3:291-294 